\title{
Macro-fungi of Karhiya Community Forest, western Terai, Nepal
}

\author{
Hari Prasad Aryal ${ }^{1 *}$ and Usha Budathoki ${ }^{2}$ \\ ${ }^{1}$ Institute of Agriculture and Animal science, Paklihawa Campus, Tribhuvan University, \\ Bhairahawa, Nepal \\ ${ }^{2}$ Central Department of Botany, Kirtipur, Kathmandu, Tribhuvan University \\ *E-mail: hahariprasadaryal06@gmail.com
}

\begin{abstract}
This is the preliminary report on mycological investigation carried out at Karhiya Community Forest, in Terai region of western Nepal. Phytogeographycally, the area lies within a narrow limit of altitude between 160 and $195 \mathrm{msl}$ in tropical deciduous riverine forest, where major dominant species of macro fungi are Amanita chepangiana, A. caesrea, A. pantherina, Macrolepiota procera, M. rhacodes, Marasamius perforans, $M$. oreades, Termitomyces clypeatus and $T$. eurhizeus. The samples collected in the present study represented 26 genera of Basidiomycetes belonging to 18 families and 30 species. The dried specimens are housed in the Nepalese herbaria (TUCH, Kath). The area embraces the mycophagus ethnic communities like Tharu, Magar, Kumal, Majhi, Thakali, Gugung, Girel and Chhantal. The mycoelements prevailing in this area need sustainable utilization and conservation.
\end{abstract}

Kew words: Western terai, Rupandehi, Karhiya Community Forest, fungi, mushroom diversity

\section{Introduction}

The investigation and study on mushrooms of Nepal has started since the contribution of Berkely (1838). The major literature concerned with the mushroom flora of the country includes Adhikari (1996, 2002, 2007, 2009, 2012), Hattori et al. (2002) and Adhikari \& Devkota (2007). Balfour-Browne (1955, 1968), Bhandary (1984), Tulloss \& Bhandary (1992), Singh (2007) Christensen et al. (2008a, b), etc have also contributed on this flora. This is a preliminary report on mycological investigation carried out at Karhiya Community Forest, Western Terai, Nepal.

\section{Study area}

The study area (Fig. 1) lies in the sacred birth place of Lord Buddha, Karhiya VDC- 8, Lumbini zone, southern belt of west Nepal. It encompasses $27^{\circ} 40^{\prime} 00^{\prime \prime}-27^{\circ} 42^{\prime} 846^{\prime \prime} \mathrm{N}$ latitude and $83^{\circ} 15^{\prime} 16^{\prime \prime}-83^{\circ} 16^{\prime} 277^{\prime \prime} \mathrm{E}$ longitude. The area occupies 269 ha land between 160 and 195 msl altitude. The average annual rainfall is $1391 \mathrm{~mm}$.

Phytogeographically the area lies typically in tropical riverine belt composed of the natural degraded plants of Shorea robusta, Acacia catechu, Dalbergia sissoo, Dalbergia latifolia, Terminalia alata, Syzygium cumini, Schleihera oleosa, Phoenix sylvestris etc. These phytodiversity and ecological conditions provide a good homeland for the growth of 
tremendous amount of parasitic, saprophytic and mycorrhizal fungi in the region. The northern belt of this area has loamy sand, while the southern belt consists of sandy loam to loamy soil. This is the virgin area for the mushroom investigation and study.

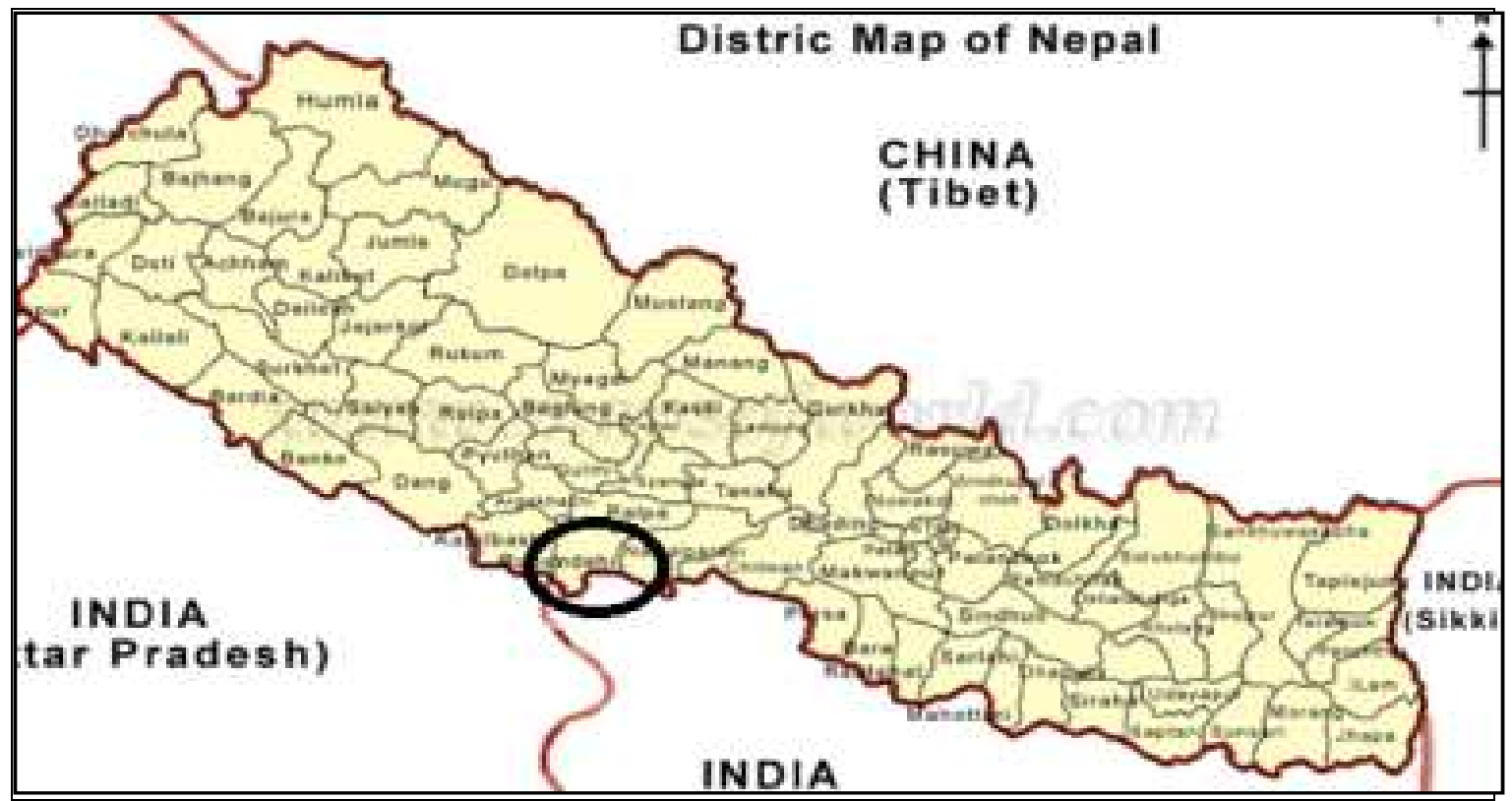

Figure 1. Collection site.

\section{Materials and Methods}

Mushrooms were collected from 15 May to 31 October, 2010 and 2011. The morphological characters including spore print were noted and photographed in their natural habitat. They were brought to the laboratory of $\mathrm{CDB}$, TU, dried well and packed in aluminum foil bags with proper tag numbers. The habit and habitat including ecological parameters viz., altitude, forest type, soil type, soil $\mathrm{pH}$, soil moisture, humidity and temperature were recorded. Mushrooms were identified consulting different literature, monographs, websites (Jstor.org; Index fungorum; tropicos.org; Mycobank.org; biodiversity library.org) and comparing with reference books (Fries, 1938; Thind, 1961; Corner, 1970; Bakshi, 1971; Mckenenny, 1971; Svreck, 1975; Heim,1977; Dickinson \& Lucas, 1979; Kibby, 1979; Phillips, 1981; Pacioni, 1985; Purukayastha \& Chandra, 1985; Singer, 1986; Imazeki et al., 1988; Kummar et al., 1990). The samples were also compared with the vouchers specimens. Specimens were deposited in the TUCH, Central Department of Botany, T.U., Kathmandu, Nepal.

\section{Results}

A total 30 species of mushrooms under 26 genera belonging to 18 families of basidiomycetes were recorded as follow.

1. Amanita caesarea (Scop.:Fr.) Pers., growing on soil in moist shady place, no.100755.

2. Amanita chepangiana Tulloss \& Bhandary, growing on soil in moist shady place, no. 100772 .

3. Amanita pantherina (DC.:Fr.) Kromb, growing on soil in moist shady place, no. 100773. 
4. Agaricus sylvicola (Vitt.) Peck., growing on soil in moist place, no. 1010524.

5. Armillariella mellea (Vahl.:Fr.) Kummer., growing on decayed log in moist shady place, no. 1008149.

6. Auricularia auricular-judae (Bull.) Wettst, on log, no. 100716.

7. Bjerkandera adusta (Fr.) Karst., in log, no. 1007120.

8. Bovista nigrrescens Pers., growing on open grassland, no. 100738.

9. Cantharellua cibariuus (Fr.:Fr.) Fr. var. amethysteus, on soil no. 100921.

10. Cerrena unicolar (Fr.) Murr., on log, no. 1007324.

11. Clavalinopsis helvola (Pers.) Murrill, growing on litter, no. 1008267.

12. Coprinus disseminates (Pers.:Fr.) Gray, growing on soil, no. 1008197.

13. Coriolus hirsutus (Fr.) Quel., on rotten log, no. 100703.

14. Flammulina velutipes (Curt.:Fr.) Karst. on soil, no. 100954.

15. Fomitopsis vinosa (Berk.) Imazeki., on log, no. 1007315.

16. Ganoderma lucidium (Fr.) Karst., on rotten trunk, no. 1007107.

17. Grifola frondosa (Dicks.: Fr.) S.F. Gray, on Quercus trees, no. 1007128.

18. Guepinia spathularia (Schw.) Fr., growing on rotten wood, no. 100715.

19. Laetiporus sulphareus (Fr.) Murr., on forest tree, no. 1007127.

20. Leucopaxillus giganteus (Sibth.) Sing. Syn. Clitocybe gigantean (Sibth.) Quel., growing on open grassland, no. 100704.

21. Macrolepiota procera (Scop.: Fr.) Singer, growing on soil, no. 1008118.

22. Macrolepiota rhacodes (Vittad.) Sing., growing on soil, no. 1008330.

23. Marasmius oreade (Bolt.:Fr.) Fr. growing on soil, no. 100740.

24. Psathyrella candolleane (Fr.) Maire, growing on log, no. 100704.

25. Pycnoporus cinnabarinus (Jacq.: Fr.) Karst. on dead wood (Betula sp.), no. 100711.

26. Ramariopsis kunzei (Fr.) Donk, on stump, no. 1008316.

27. Russula nigricans (Bull.) Fr., growing on moist shady place, no. 100751.

28. Termitomyces clypeatus R. Heim on termites nest, no. 1010530.

29. Termitomyces eurhizeus (Berk.) Heim., on termites nest, no. 1007119.

30. Tyromyces sambucens (Lioyd) Imaz., growing on log, no. 100718.

A notable frequency of Amanita chepangiana, A. caesarea, A. pantherina, Macrolepiota procera, $M$. rhacodes, Termitomyces clypeatus and T. eurhizeus were observed in the study area. More than $50 \%$ of mushrooms were of Agaricales followed by Polyporales (Table 1).

Table 1. Frequency of groups of Basidiomycotina (30 spp).

\begin{tabular}{lccccccc}
\hline Taxa & Agar & Aur & Can & Pha & Poly & Russ & Tre \\
\hline Tns & 16 & 1 & 1 & 1 & 9 & 1 & 1 \\
SF & 53.33 & 3.33 & 3.33 & 3.33 & 30 & 3.33 & 3.33 \\
\hline
\end{tabular}

Tns= Total number of species, $\mathrm{SF}=$ Species frequency, Agar= Agaricales, Aur $=$ Auriculariales, $\mathrm{Can}=$ Cantharellales, $\mathrm{Pha}=$ Phallales, Poly $=$ Polyporales, Russ $=$ Russulales, The $=$ Theleophorales, Tre $=$ Tremellales 


\section{Discussion}

The gathering of mushrooms revealed that there were plenty of species, which were edible and of medicinal value. Many mushroom species are gathered by local people for their daily livelihood and trade. They are sacked in bags and carried to India for sell. The tropical species like Agaricus sylvicola seem to be widespread in the terai belt of Nepal. The medicinally important tropical polypore like Pycnoporus cinnabarinus is gathered for the remedy of infectious disease. Two species of Termitomyces, the tropical African element, prevail in this area, which are distributed from South Africa to the Indian sub continent. Their market price fluctuates in between 5 and 6 US Dollar $/ \mathrm{kg}$. The local ethnic casts pronounce the mushrooms as Vavnethi / Bhuenphor / Bagale / Deuule (Termitomyces spp.), Sallecheu (Amanita spp), Pattecheu / Gobbre (Macrolepiota procera) etc.

On the basis of population density and dynamics, the species abundance found during field study were Amanita chepangiana, A. caesrea, A. pantherina, Macrolepiota procera, M. rhacodes, Termitomyces clypeatus and T. eurhizeus, repectively. The increasing depletion of sal forest is an alarming signal in the appearance, distribution and dominance of these species. The present investigation shows that the pure stand of Shorea robusta favors the growth of numerous species of mushroom flora. The litter debris of Shorea robusta favors the regulation of temperature in the soil.

So, it is visualized from the field survey that some of the important species need special attention to conserve against the threat to avoid their unmanaged and unscientific exploitation by the people. It is therefore necessary to conserve natural habitat of mushroom diversity for the sustainable development. The government should take special attention on these aspects.

\section{Acknowledgments}

The first author is thankful to NAST (Nepal Academy of Science and Technology), Nepal for providing the research grant and Tribhuvan University, Institute of Agriculture and Animal Science for granting study leave.

\section{References}

Adhikari, M.K. \& S. Devkota. 2007. The clavarioid fungi of Nepal. Bulletin of Department of Plant Resources 29: 7-22.

Adhikari, M.K. 1996. Biodiversite des Basidiomycetes au Nepal: etude systematique et biogeographique. Specialite Ecologie-Mycologique. These du Doctorat de I'Universite present devant I'Universite aul Sabatier, Toulouse, France. No. d'ordre 2309. 205p.

Adhikari, M.K. 2000. Mushrooms of Nepal. P.U. Printers, Kathmandu, Nepal.

Adhikari, M.K. 2007. Mushroom diversity in Nepal: In: Glimpse in Mycological and Mushroom production in Nepal. Organized by Mycological and Phytopathological Society of Nepal, $18^{\text {th }}$ June, 2007.

Adhikari, M.K. 2009. Researches on the Nepalese mycoflora (Revised account on the history of mycological Explorations). Kathmandu, Nepal. pp. 90.

Adhikari, M.K. 2012. Researches on the Nepalese mycoflora-2: Checklist to macro-fungi (Mushrooms). Publ. K.S. Adhikari, Kathmandu, Nepal. 90p.

Bakshi, B.K. 1971. Indian Polyporaceae. Indian Council of Agriculture Research, New Delhi. 
Balfour-Browne, F.L. 1955. Some Himlayan fungi. Bull. Brit. Mus. (Nat. Hist.) Ser. Bot. 1: 189218.

Balfour-Browne, F.L. 1968. Fungi of recent Nepal expendition. Bull. Brit. Mus. (Nat. Hist.) Ser. Bot. 4: 99-141.

Berkeley, M.J. 1838. Description of exotic fungi in the collection of Sir W.J. Hooker from memories and notes of J.F. Klotsch with addition and correction. Ans. Natutal History 3: 375-401.

Bhandary, H.R. 1984. Mushrooms. In: Nepal Nature's Paradise (Ed. T.C. Majapuria), Bangkok. White Lotus Comp. Ltd. pp. 225-247.

Christensen, M., S. Bhattarai, S. Devkota \& H.O. Larsen. 2008a. Collection and use of wild edible fungi in Nepal. Eco. Bot. 62(1): 12-23.

Christensen, M., S. Devkota \& S. Bhattarai. 2008b. Use of wild edible mushrooms in the Annapurna conservation area, Nepal. Jour. Mycol. Phytopath. Soc. Nepal 1: 1-6.

Corner, E.J.H. 1970. Supplement to a monograph of Clavaria and allied genera. Nova Hedwigia 33 Verlag von. J. Cramer.

Dickinson, C. \& J. Lucas. 1979. Encyclopedia of Mushrooms. Orchid Publication, London.

Fries, E.M. 1938. Epicrisis Systematics mycologici. Upasala.

Hattori, T., M.K. Adhikari, T. Suda \& Y. Doi. 2002. A list of Polypores (Basidiomycotina, Apyllophorales) collected in Jumla, Nepal. Bull. Natl. Sci. Mus. Ser B, 28(2): 27-38.

Heim, M.R. 1977. Termites Et Champignons Boubee. Societe nouvelle Des Editions Boubee 11, Place Saint-Michel. Paris 6.

Imazeki, R., Y. Otani \& T. Hongo. 1988. Coloured illustration of fungi of Japan. YAMAKEI Publishers Co. Ltd., Tokyo, Japan.

Kibby, G. 1979. Mushrooms and Toadstools. Oxford University Press, London.

Kummar, A., R.P. Bhatt \& T.N. Lakhanpal. 1990. The Amanitaceae of India. Bishen Sing Mahendra Pal Singh, 23-A, Deharadun, India.

Mckenenny, M. 1971. The savory wild mushroom. University of Washington press, USA.

Pacioni, G. 1985. The Mcdonald's encyclopedia of mushrooms and toadstools. Mcdonald \& Co. Ltd. London.

Phillips, R. 1981. Mushrooms and other fungi of Great Britain and Europe. Pan Book Ltd. London.

Purukayastha, R.P. \& A. Chandra. 1985. Manual of Indian Edible Mushrooms. Jagendra Book Agency. New Delhi, India.

Singer, R. 1986. The Agaricales in Modern Taxonomy ( $4^{\text {th }}$ edition). Bishen Singh Mahendra Pal Singh, Dehradun, India.

Singh, S.C. 2007. Status of mushroom cultivation in Nepal with reference to world production and consumption trends. In: Mycological research and mushroom production in Nepal. Published by the mycological and Phytopathological society, Nepal. pp. 1-19.

Svreck, M. 1975. A colour guide to Familiar Mushrooms. Octopus Book Company.

Thind, K.S. 1961. The Clavariaceae of India. ICAR, New Delhi. 197p.

Tulloss, R.E. \& H.R. Bhandary 1992. Amanita chepangiana; a new species from Nepal. Mycotaxon. XLLIII: 25-31. 